\title{
Analisys of Welding Crack on The Under Frame of Wagon for Cement Bags Transportation Using Euro Code, Measurement and Finite Element
}

\author{
Agus Sasmito ${ }^{1}$, Yudi Irawadi $^{1}$, and Hary Soebagyo ${ }^{1}$ \\ ${ }^{1}$ Agency for The Assessment and Application of Technology, B2TKS-BPPT, Gd.220, Komplek Puspiptek, Setu, \\ Tangerang Selatan, Banten-15314, Indonesia
}

\begin{abstract}
The Underframe of Wagon steel structure have both complex geometry and loading conditions producing complex Underframe structure behaviour which is hard to estimate and analyse using the traditional fatigue calculation methods. The impacts of th e loading direction, loading type and detail geometrical shapes, i.e. Underframe components which are working in a group, need to be considered carefully in the stress analysis. Using the assumption of elastic behavior for all the underframe structural systems, in which sources of stress increased that have significant effects on the fatigue strength capacity are several included, can over/lower yield stress values to be analyzed in fatigue design. The application of the advanced stress assessment methods in the welding area using the Euro Code calculation studied in this paper produces more accurate stress results that can explain welding crack during operation in The car body of Wagon Steel. Based on Euro Code stress assesment, FEM analysis and measurement can be known that crack on the welding joint of wagon bottom part due to lack finishing of the welding joint. The IIW recommendations can be use in order to repair welding joint finishing to avoid crack fatigue.
\end{abstract}

\section{Introduction}

In the manufacturing of wagons structure, The components and assemblies are commonly joined by welding process. The specifications which must be fulfilled for each welded construction are reliability and safety during working. Finite element method (FEM) can be used for numerical analysis of welded joints of under frame wagon structure [1]. The prediction and the multibody dynamic analysis for the fatigue life of the $220 \mathrm{t}$ mining truck frame structure and the fatigue life analysis method are presented in [2].

According to GB/T27025-2008, the dynamic stress test of the whole truck is implemented to obtain the peak stress of the mainly forced area and it is compared with the simulated stress [1]. According to GB/T27025-2008, the dynamic stress test of the whole truck is perform to get the peak stress data of the primary forced area and the data is compared with the FEM stress simulation [1]. Fatigue strength assessment for the bogie frame structure in the Korean tilting train has been done by analytical and static tests in [3]. The stress areas of the bogie frame were evaluated using simulation. All stresses value were below the welding line criteria of Goodman diagram. Based on the fatigue assessment, the bogie frame satisfied structural and fatigue safety [1].

The "IIW Recommendations for Fatigue Design of Welded Components and Structures" have been published firstly in 1996 [4], The recommendations include all current methods of validation, as e.g. component testing, nominal stress calculation, structural stress testing, and notch stress method using fracture mechanics evaluation approaches. Detailed guidelines for evaluation and assessment of weld defect was also given. The safety philosophy covered the different strategies, which are applied in several fields of application and gave a detailed choice for the designer. The update of the recommendations was finished in 2006 [5]. Some new items have been included. Finite element meshing for using of the structural hot spot analysis method has been evaluated in a new way. comprehensible guidances have been given to avoid different engineering assessments for meshing in

Corresponding author: agus.sasmito@bppt.go.id, yudi.irawadi@bppt.go.id, hary.soebagyo@bppt.go.id 
different design workplaces. Some types of meshing have been generated, a fine meshing and a coarse meshing. The next is the introduction of post-weld treatment for enhancement of fatigue strength. It was established that this possibility exists, a numerical assessment at the design step without following tests was not feasible. Now a minimum usable improvement is given, which can be used without verification tests [6].

The methodology applied to identify causes of cracking around the welded joint on the structure of wagon type Sgmns for the transportation of containers and swap bodies is explained in [1]. Because of complicated mounting, bending and welding of underframe structure bottom part, it was not feasible to resolve this matter with a commercial software. The objective of the analysis is to identify and listing the residual stresses that seem after the mounting working of the underframe bottom part structure. In accordance with the TSI standard and norm EN 12663:2000.

In this paper, will be used the methodology described in [1] and use actual load for verifycation the strength of the weld on the welding steel wagon underframe and determine the cause of the crack in the view of the strength of the weld in receiving multiaxial load.

\section{Europan standards}

According to [1], The frequently used European standards for wagon evaluation are: TSI standard, British Standard (BS EN 12663:2000) and Eurocode 3: Part 1.9. TSI standard determine the load cases for testing of freight wagons. According to TSI, Clause 4.2.2.3.1, it is mandatory to examine wagon underframe structure in correlation to different category of load (static and dynamic), with the requirements of Section 3, BS EN 12663. for computing the fatigue strength of underframe freight wagons correspond to vertical load, in accordance with the standard TSI Annex CC and BS EN 12663, the dynamic load is in range about $30 \%$ of vertical static load. For the fatigue examination of welded joints of wagons, the most usually used standard is Eurocode 3 Part 1.9. According to Eurocode 3 Part 1.9 equivalent stress in the welds is calculated as Equation 1:

$$
\sigma_{w f}=\sqrt{\sigma_{\perp f}^{2}+\tau_{\perp f}^{2}}
$$

where $\sigma_{\mathrm{wf}}$ is the equivalent normal stress, $\mathrm{G}_{\mathrm{wf}}$ the equivalent tangential stress, $\sigma_{\square}$ the normal component of stress, $\sigma_{\square \mathrm{f}}$ the tangential component of stress, and $\mathrm{G}_{\mathrm{lf}}$ is the tangential component of stress (parallel with welded joint).
The directions of stresses in the welded joint in accordance with Eurocode 3 and Equation. (1) are shown in Figure 1. This process covers two areas of cyclic stresses with different characteristic. In each of these areas, the failure happen under different procedures. In the first problem, plastic strains take place, while in the second case, stresses and strains are elastic. The first case (the low cycle fatigue) implicate a small amount of cycles (up to 104), and larger loads. The second case (the high cycle fatigue) in-volves a large number of cycles (over $10^{4}$ ) and a smaller load.

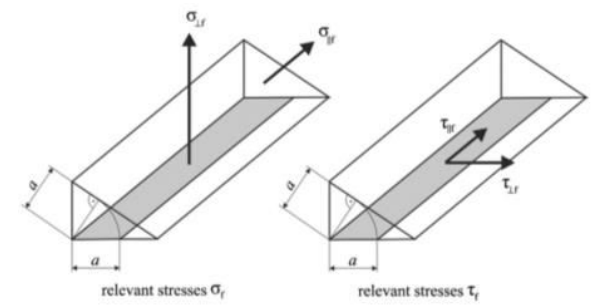

Fig. 1. Stresses in the welded joints in accordance with Eurocode 3.

August Wöhler, German engineer, set up and conducted research of fatigue analysis. The tests are based on cyclic loading of axles of freight wagons in bending, torsion and alternating pressure and tension test specimens of different materials. The results were systematized in form of diagrams (Figure 2). The Wöhler or S-N curves shown in Figure 2 present the ratio of direct stress range and the number of cycles to failure.

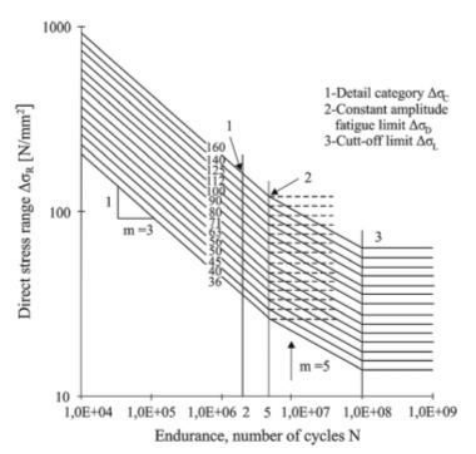

Fig. 2. Wöhler's curves ( $\mathrm{S}-\mathrm{N}$ curves).

Based on Euro Code 3 [7], The relation of direct stress range and number of cycle in log number is shown as Equation 2.

$$
\log N=\log a-m \log \Delta \sigma_{R}
$$


Where, Log a can be determined using Table 1.

Table 1. The relation value stress cattegory and $\log a$, stress fatigue amplitud and cutt-off limit.

\begin{tabular}{|c|c|c|c|c|}
\hline \multirow{2}{*}{$\begin{array}{c}\text { Detail } \\
\text { Category } \\
\Delta \sigma_{\varepsilon} \\
(\mathrm{Mpa})\end{array}$} & \multicolumn{2}{|c|}{$\log$ a for $\mathrm{N}<10^{5}$} & \multirow{2}{*}{$\begin{array}{c}\text { Constant } \\
\text { Amplitude } \\
\text { Fatigue } \\
\text { Limit } \\
(\mathrm{N}=5 \mathrm{x} \\
\left.10^{6}\right) \\
\Delta \sigma_{D}(\mathrm{Mpa})\end{array}$} & \multirow{2}{*}{$\begin{array}{c}\text { Cutt-of } \\
\text { limit } \\
\left(\mathrm{N}=10^{5}\right) \\
\Delta \sigma_{L} \quad(\mathrm{Mpa})\end{array}$} \\
\hline & $\begin{array}{c}\mathrm{N} \leq 5 \mathrm{x} \\
10^{6} \\
(\mathrm{~m}=3)\end{array}$ & $\begin{array}{c}\mathrm{N} \geq 5 \mathrm{x} \\
10^{6} \\
(\mathrm{~m}=5)\end{array}$ & & \\
\hline 112 & 12.451 & 16.036 & 83 & 45 \\
\hline 100 & 12.301 & 15.786 & 74 & 40 \\
\hline 90 & 12.151 & 15.536 & 66 & 36 \\
\hline 80 & 12.001 & 15.286 & 59 & 32 \\
\hline 71 & 11.581 & 15.036 & 52 & 29 \\
\hline 63 & 11.701 & 14.786 & 46 & 26 \\
\hline 56 & 11.551 & 14.536 & 41 & 23 \\
\hline 50 & 11.401 & 14.286 & 37 & 20 \\
\hline 45 & 11.231 & 14.036 & 33 & 18 \\
\hline 40 & 11.101 & 13.786 & 29 & 16 \\
\hline
\end{tabular}

In Figure 3 is shown pulsating stress as the sinus function shape and the idealized form of load is presented.

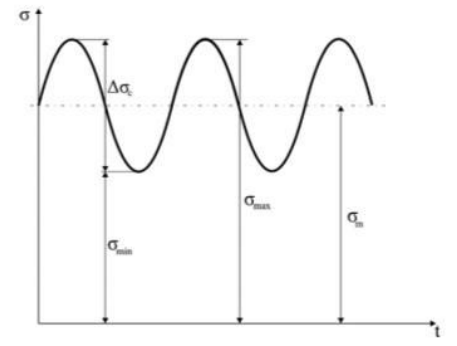

Fig. 3. Pulsating stress.

According to the EN 1993-1-9 [7], Stress ratio for Figure 3 can be determined using equation 3 .

$$
R=\sigma_{\min } / \sigma_{\max }
$$

The material for wagon's understructure is used SS 400 with the yield strength is $245 \mathrm{Mpa}$. For vertical static safety load design, the vertical static stress is limited to $75 \%$ of yield. Then the dynamic load is used in the range $30 \%$ of vertical static stress, so that the stress ratio can be calculated using equation 3, Based on it,Table 1 and Equation 3 can be determined for R value;

$$
\begin{aligned}
R & =(245 \times 0.75)-(245 \times 0.75 \times 0.3) /(245 \times 0.75)+(245 \times 0.75 \times 0.3) \\
& =0.538
\end{aligned}
$$

According to EN 1993-1-9 Table 8.4 the detail category for welding connection is 40 of gusset plate welded to the edge of a plate or beam Flange, and the direct stress range is $\Delta \sigma_{C}$ is $40 \mathrm{Mpa}$, From Table 1 the value of $\log$ a for $m=3$ is 11.101 , and constan stress amplitude limit $\Delta \sigma_{D}$ is $29 \mathrm{MPa}$.

Based on Figure 3, Equations 2 and 3, can be obtained the stress maximum at the dynamic load based on static analysis as shown as Equation 4.

$$
\begin{aligned}
\sigma_{\text {mazlim }} & =\Delta \sigma_{D} /(1-R) \\
& =2.164 \Delta \sigma_{D} \mathrm{MPa}
\end{aligned}
$$

The limit stress for safe life calculated by equation Equation. 4, in this equation stress maximum limit divided by parsial factor for fatique strength at low consequence $\left(\gamma_{m f}=1.15\right)$ and high consequence $\left(\gamma_{m f}=\right.$ $1.35)$

$$
\sigma_{\text {safelim }}=\sigma_{\max } / \gamma_{\operatorname{mf}}
$$

The values of permissible stress for static test to verify fatigue strength of welded joints in steel SS 400 in accordance with Eurocode 3 Part 1.9 are shown in Table

\begin{tabular}{|c|c|c|c|c|}
\hline \multirow{2}{*}{$\begin{array}{l}\text { Detail } \\
\text { Category } \\
\Delta \sigma_{c} \\
\text { (Mpa) }\end{array}$} & \multirow{2}{*}{$\begin{array}{c}\text { Constant } \\
\text { Amplitude } \\
\text { Fatigue } \\
\text { Limit } \\
(\mathrm{N}=5 \mathrm{x} \\
\left.10^{6}\right) \\
\Delta \sigma_{D} \text { (Mpa } \\
\text {, }\end{array}$} & \multirow{2}{*}{$\begin{array}{l}\text { Permissible } \\
\text { maximum } \\
\text { fatigue stress } \\
\sigma_{\text {maslim }} \\
\text { (Mpa) }\end{array}$} & \multicolumn{2}{|c|}{$\begin{array}{l}\text { Limit stress for safe life } \\
\qquad \sigma_{a a f c}(\mathrm{MPa})\end{array}$} \\
\hline & & & $\begin{array}{c}\text { Low } \\
\text { consequence } \\
\gamma_{m f}=1.15\end{array}$ & $\begin{array}{c}\text { High } \\
\text { Consequence } \\
\gamma_{m, f}=1.35\end{array}$ \\
\hline 112 & 83 & 179,612 & 156,184 & 133,046 \\
\hline 100 & 74 & 160,136 & 139,249 & 118,619 \\
\hline 90 & 66 & 142,824 & 124,195 & 105,796 \\
\hline 80 & 59 & 127,676 & 111,023 & 94,575 \\
\hline 71 & 52 & 112,528 & 97,850 & 83,354 \\
\hline 63 & 46 & 99,544 & 86,560 & 73,736 \\
\hline 56 & 41 & 88,724 & 77,151 & 65,721 \\
\hline 50 & 37 & 80,068 & 69,624 & 59,310 \\
\hline 45 & 33 & 71,412 & 62,097 & 52,898 \\
\hline 40 & 29 & 62,756 & 54,570 & 46,486 \\
\hline
\end{tabular}
1. In Table 2 are shown the values of permissible stress for static fatigue testing of welded joints in accordance with Eurocode 3 Part 1.9, Figure . 7.1.

Table 2. Limit stress values for static test to verify fatigue strength in steel SS 400 .

$$
\begin{aligned}
& D_{1}=f_{\text {ele }}\left(0.5 t_{\text {neighbor }}+t_{\text {min }}\right)=1 \cdot\left(0.5 t_{2}+t_{2}\right) \\
& D_{2}=f_{\text {ele }}\left(0.5 t_{\text {neighbor }}+t_{\text {min }}\right)=1 \cdot\left(0.5 t_{1}+t_{2}\right)
\end{aligned}
$$

Figure 1 and Equations. (3) and (4) show the manner of determining the size of the weld zone for 
FEM analysis. Figure 5 shows appro-priate finite element model of welded joints.

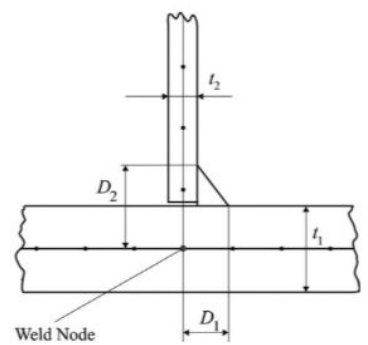

Fig. 4. Size of the weld zone for FEM calculation.

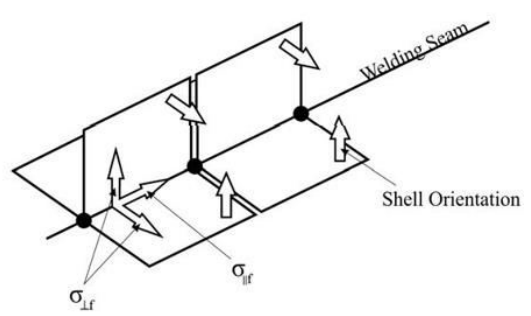

Fig. 5. Proper orientation of the shell element in the weld zone.

\section{Cracks on bottom side of wagon underframe for cement bags transportation}

The wagon (Figure. 6) of the Indonesian Railways Company is designed for the transportation of containers and cement bags, within block trains. The bottom side of underframe is made of steel plates and rolled steel profiles, as a welded construction. On the upper part of underframe there are securing devices, in form of container locks (for the fixation of containers) and make wood when the wagon use for cement bags transport, Figure 8 .

About 40 percent of about 1000 wagons, which were used in transport, have failure or initial crack. After visual inspection of the wagons, cracks and failure were inspected on the bottom side of underframe structure, Figure. 7. Base on to this fact, it was important to determine the reason for the presence of the crack growth on the wagon bottom side of underframe structure. The observed cracks seem on the welded joint or near the welded joint of two plates which close rolled steel profile of bottom side of underframe structure. The observed cracks appear on the welded joint or near the welded joint of two plates which close rolled steel profile of bottom side of underframe, Figure. 9. We tried to determine cracking causes using FEM analysis, according to mentioned standards and actual condition of loading.

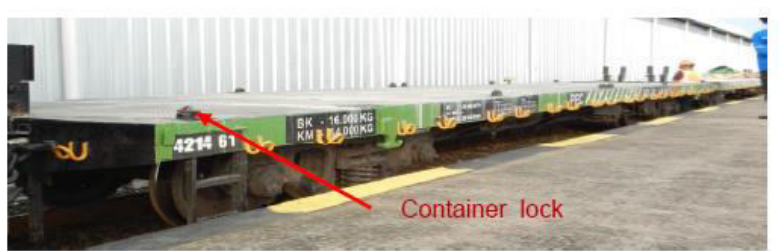

Fig. 6. The Indonesian Railways Wagon for transportation of containers and cements.

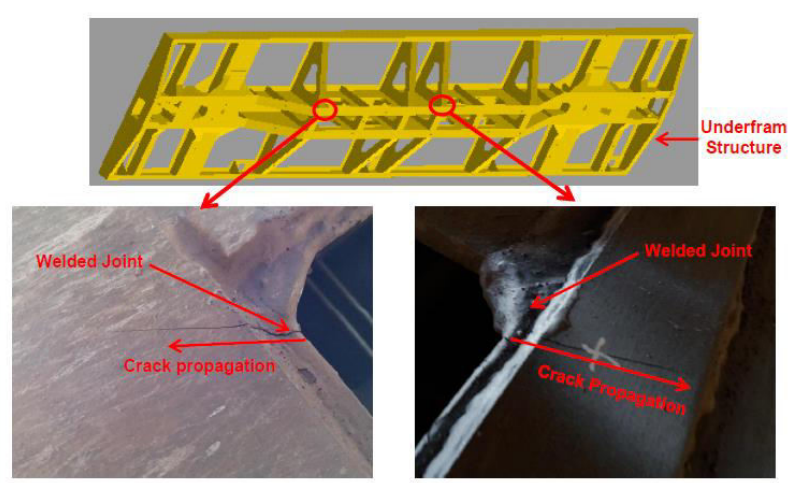

Fig. 7. Initial crack and crack propagation on the base metal nearby welded joint in the underframe structure.

\section{Service Loads}

\subsection{Standard Requirement}

Standard Requirement Commonly the service load case is specified by TSI standard [8], Clause 4.2.2.3.3 and BS EN 12663:2000) [9], Clause 4.6, 5.2, Table 16. Limit values for static test to check fatigue strength, determined for minimum number of two million constant amplitude cycles, using Eurocode 3, Table 1.

According to standards UIC 592-4 [10], point 1.1.1.1 and 1.1.1.2 and UIC 592-2 [11], point 2.3, all vertical load cases are examined.

Base on the TSI standard [8], Annex YY.2., besides the criterion suggest that the permitted stress values must not be passed, also maximal deflection on the underframe structure should not more than $3 \%$ of the wheelbase or of the bogie pivot pitch from the first position.

In actual usage, the wagon is used to transport the cement bags, the vertical load comes only from the cement bags, The load is placed on the wagon with the position as shown Figure 8. 


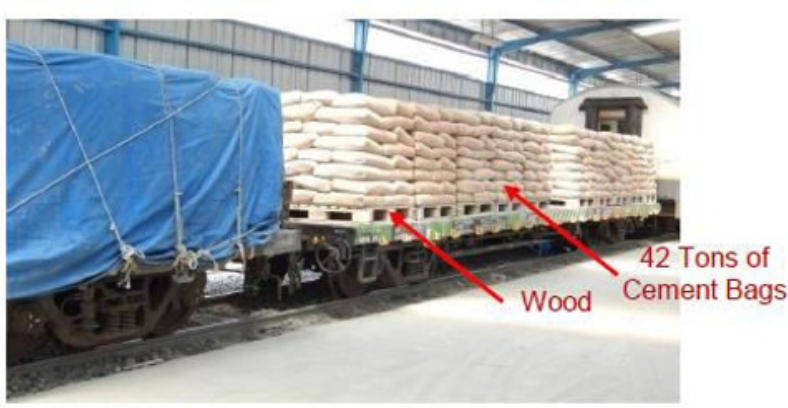

Fig. 8. Loading scheme position of cement bags.

\subsection{Finite Element Modelling for analysis of underframe wagon stress}

For the most conventional wagon designs, the loading defined in Table 16 of British Standard (BS EN 12663:2000) [9] is considered as sufficient to represent the full effective combination of fatigue load cycles. The source of fatigue loading is determined according to TSI standard [8], Annex CC. The dynamic load used in design is in range of $30 \%$ of vertical static load. For all load cases linear static analysis was performed. Structural steels JIS G3101 SS 400 (with $245 \mathrm{MPa}$ as yield, $400 \mathrm{Mpa}$ Tensile strength) are used for cross beam and middle bottom part, JIS SM 490 A (with $325 \mathrm{MPa}$ as yield, $510 \mathrm{Mpa}$ Tensile strength) are in the side sill, gusset and bolster. Both types of steel have same material characteristics $(7.7 \mathrm{E}+0.4 \mathrm{Mpa}$ as Shear Modulus, $7.85 \times 10^{-6} \mathrm{~kg} / \mathrm{mm}^{3}$ density and $2.07 \mathrm{E}+05$ Mpa as Young Modulus of Elasticity, and 0.3 Poisson ratio). The reaction of the structure of the wagon due to loading are analyzed by Finite Element Methode (FEM), boundary condition based on actual usage for modeling of vertical loading is shown in the Figure 9. The cement load 42 ton is divided into two segment, spesified as uniform load on the surface of the wagon, and there are two support position in the wheel set of wagon.

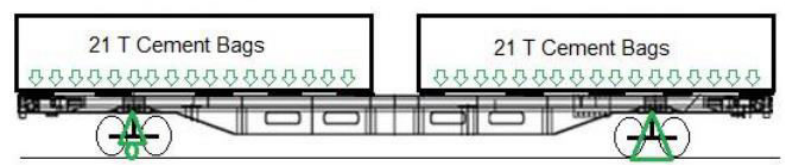

Fig. 9. Scheme of model loading - vertical load mass $42 \mathrm{t}$ for finite element analysis.

Figure 10, FEM display model of underframe for stress analysis, according Hobbacher, A [6], one of the proper messhing type for underframe structure is solid mesh. Figure 11 show boundary condition in underframe of wagon. Figure 12 is Von Mises equivalent stress field, where the tress on the top surface of wagon only $31 \mathrm{Mpa}$ and highest stress is on the underframe of wagon, Figure 13 about maximum von misses equivalent stress of vertical loads from cement bags mass, where the maximum value is $279 \mathrm{MPa}$. The von misses stress on the crack position shown at Figure 14, it seem that the von misses is vary from 0 to $124.122 \mathrm{Mpa}$ in the welding joint area of underframe structure, and it is around to the crack position.

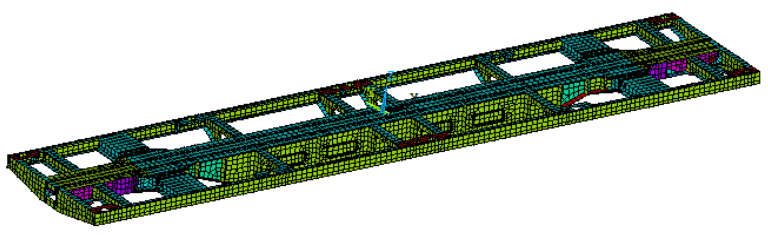

Fig. 10. FEM Model and messhing for underframe of wagon.

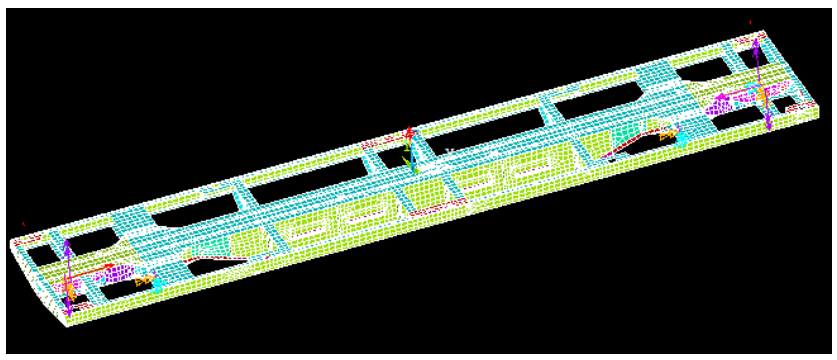

Fig. 11. Boundary Condition in underframe wagon.

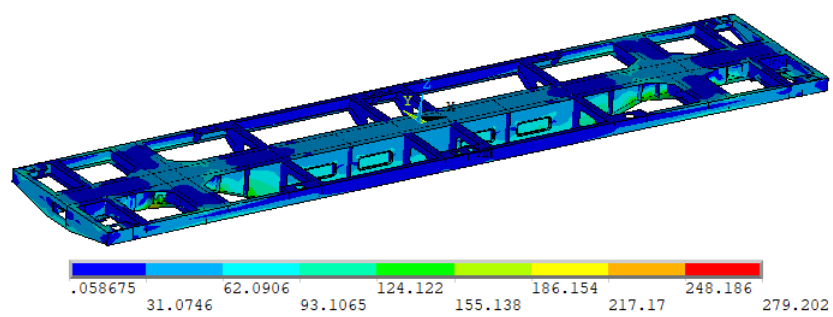

Fig. 12. Von Mises equivalent stress field.

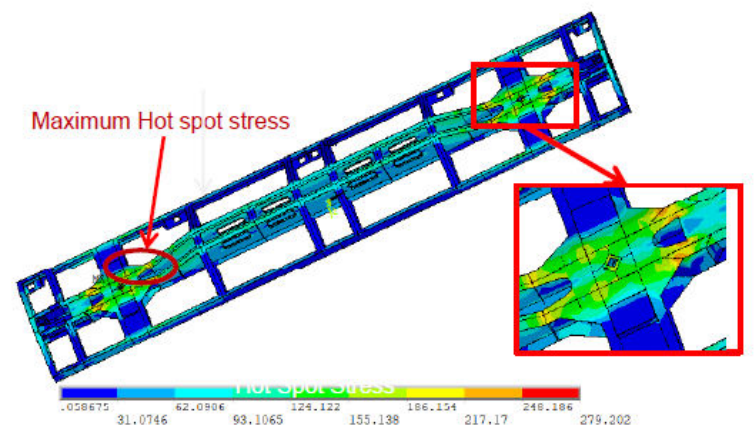

Fig. 13. Maximal Von Mises equivalent stress of underframe wagon. 


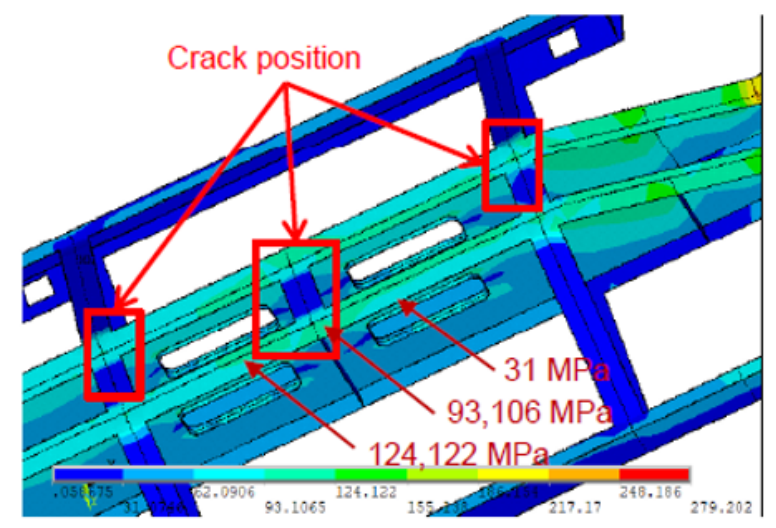

Fig. 14. Place of welding plates which close profile of bottom part of underframe - Von Mises equivalent stress field.

The maximum deflection value on the wagon is shown in the Figure 15. It appear that the maximum deflection is $1.35 \mathrm{~mm}$. The deflection is under total maximum deflection according to TSI standard.

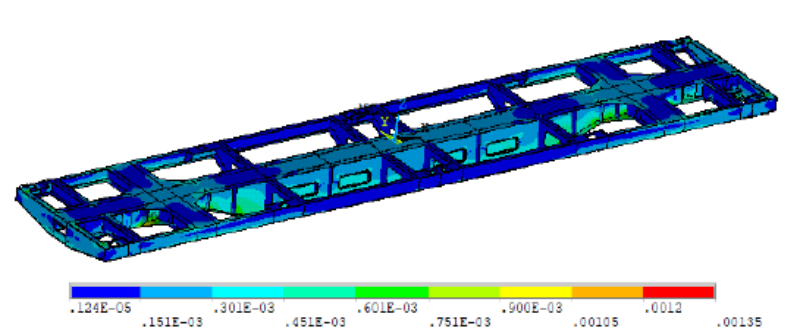

Fig. 15. Deflection of wagon structure.

Maximum value as a result of calculated stress and significant loaded region are shown in Figure 13. Some of this stress areas are in the welding joint. The values of calculated stresses in this stress areas are under the limit stress for safe life in parent material in accordance with Eurocode 3: Part 1.9 [7], Table 1.

According to Table 1 for detail category 40 of gusset plate welded to the edge of a plate or beam Flange, the welds limit maximum stress is $54.570 \mathrm{MPa}$ for low consequence and $46.486 \mathrm{Mpa}$ for high consequnce. According to calculation results at the place of weld, Figure 14, stress is about $93 \mathrm{MPa}$, but at a particular location close to the crack weld joint the stress value increase up to $124.122 \mathrm{Mpa}$. It is not safe because the stress value is higher than limit stress for safe life, also higher than permissible maximum fatigue stress limit in Table 1.

On the basis of these facts, it can be concluded that the cracks on wagon are caused by service load. To verify this and the FEM result analysis, here for will be established the measurement on the actual condition.
According to Haagensen [12], the enhancement in fatigue strength can be perform by smoothing transition of join welding.

\subsection{Measurement for underframe wagon stress}

The measurements on the wagons are perform to ensure that the stress from FEM simulation results in the welding area are correct, furthermore it can be realizaed a load that cause the crack occurring at the weld joint area.

The static test for stress measurements were made using the load 42 tons of cement bags, as shown in Figure 16. The strain gauge was attached to the wagon underframe before the maximum vertical load was applied, when the wagon was loaded, all strain value in the wagon underframe were recorded as data for stress calculation.

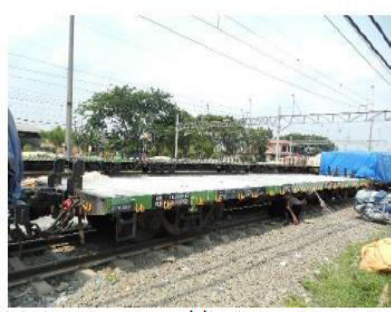

(a)

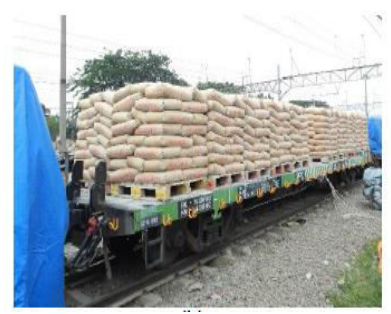

(b)
Fig. 16. The wagon specimen for measurement of underframe stress. (a) tare load without loading, (b) the wagon with full load 42 tons of cement bags.

Setting up of the strain gauge is determined based on the position of the crack Figure 7 and FEM analysis, as shown on figures 12 to 16 . The method of strain gauge installed is shown in Figure 17, and the location of the strain gauge mounting is shown in Figure 18.

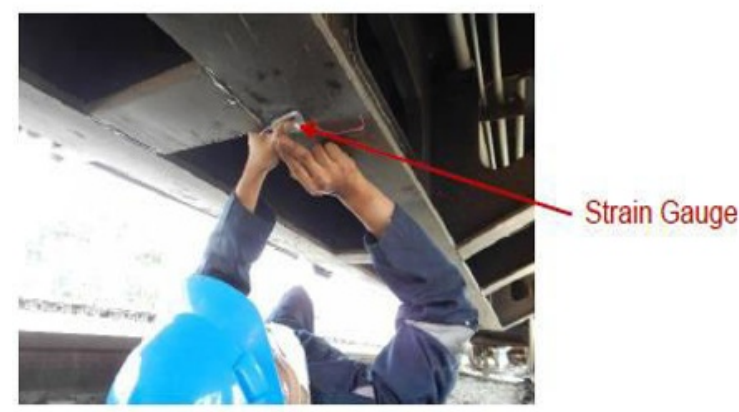

Fig. 17. Assembly of strain gauge on the underframe wagon based on FEM analysis. 


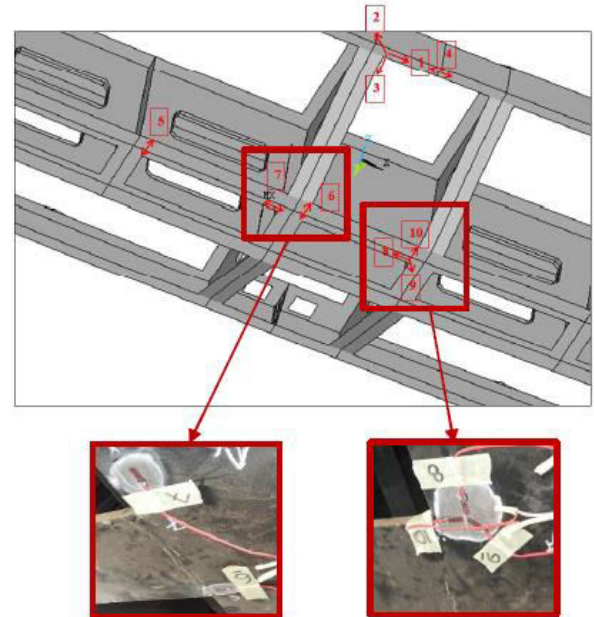

Fig. 18. Strain gauge position nearby on the welding crack area for stress measurement.

In the measurement are obtained the stress value at the specified position. All the measurement data will be analyzed and compared to FEM stress result. The stress and strain measurement data is shown on the Table 3.

Table 3. The Stress and strain measurement result of underframe wagon structure

\begin{tabular}{|c|c|c|c|c|c|}
\hline No & $\begin{array}{c}\text { Strain } \\
\text { Gauge } \\
\text { Number }\end{array}$ & $\begin{array}{c}\text { Strain } \\
(\mu \mathrm{m} / \mathrm{m})\end{array}$ & $\begin{array}{c}\text { Stress } \\
(\mathrm{Mpa})\end{array}$ & $\begin{array}{c}\text { Equivalent } \\
\text { Stress } \\
(\mathrm{Mpa})\end{array}$ & $\begin{array}{c}\text { Strain } \\
\text { gauge } \\
\text { type }\end{array}$ \\
\hline 1 & 7 & 313 & 64.79 & 65.79 & Single \\
\hline 2 & 8 & 279 & 57.75 & & \\
\cline { 1 - 4 } 3 & 9 & 100 & 20.70 & \multirow{2}{*nnnn}{57.76} & Rossete \\
\cline { 1 - 4 } 4 & 10 & -14 & -2.90 & & \\
\hline
\end{tabular}

The data in the Table 3 show that the stress for strain gauge number 7 is $65.79 \mathrm{MPa}$, it is conform with the FEM result, Figure 14, where at that location the stress vary from 62.091 Mpa to 93.106 $\mathrm{MPa}$, depending on the spesific strain gauge position, where as the rosette strain gauge number $8-10$, the equivalent stress is 57.76 Mpa. This stress value is acceptable, because in that location, the stress is have smooth transition from 31 Mpa to 124.122 Mpa. Based on it, the FEM simulation is valid.

Even though the stress of the measurement Table 3 is lower than the FEM stress analysis Figure 4, but the stress of strain gauge is higher than Limit stress for safe life high consequence for welding joint detail category $\Delta \sigma_{c} 40 \mathrm{Mpa}$, Table 2. Based on this the conclusion is the same as FEM analysis, the cracks on wagon are caused by service load.
Improving accuracy of measurement can follow the methode confirm to Hobacher [6], in order to measure the stress at the hot spot joint, there are guidances for the strain gauge position. When compared hobacher procedure for hot spot measurement [6], the strain gauge placement in Figure 18 should be closer to the welded joint area, and the measurement result can obtain actual hot spot stress.

\section{Conclusions}

Analyzing obtained results both FEM analysis and measurement which is compared on standard, it was concluded that stress strength of the welding joint on the bottom part of wagon underframe does not satisfy requirements according to the standards. The lack finishing of welding produces high stress concentration, low detail category $\left(\Delta \sigma_{c}\right)$ and low limit stress for safe life $\left(\sigma_{s a f \theta}\right)$. The stress occur on the service load that higher than limit stress for safe life $\left(\sigma_{s a f e}\right)$ induce cracks fatigue in the zone of welded joint. There are need softening of transition in the joint part to avoid any stress concentration, and to increase detail category $\Delta \sigma_{c}$.

In further research, the strengthening profiles and softening joint part transition should be placed in the areas with identified cracks. New FEM analysis and measurement of wagon is not required, but softening joint part transition should be done and static and fatigue strength should satisfy requirements according to standards. The new softening solution for the welding joint according to IIW recommendation in the bottom part of underframe will be proposed.

The authors acknowledge the Indonesian Railways Company "PT. Kereta Api Indonesia", The Indonesian Rolling Stock Manufacturing Corporation, Ltd "PT. Industri Kereta Api Indonesia" for the provision of wagon test specimens and Prof. Harkali setyono. Phd for the advice.

\section{References}

1. Vladimir Milovanovic, Vladimir Dunic, Dragan Rakic, Miroslav Z ivkovic. : Identification causes of cracking on the underframe of wagon for containers transportation - Fatigue strength assessment of wagon welded joints, Engineering Failure Analysis, (10 February 2013).

2. Mi C, Gu Z, Yang Q, Nie D. Frame fatigue life assessment of a mining dump truck based on finite element method and multibody dynamic analysis. Eng Fail Anal (2012);23:18-26.

3. Kim JS. Fatigue assessment of tilting bogie frame for korean tilting train: Analysis and static tests. Eng Fail Anal (2006);13(8):1326-37. 
4. Hobbacher A. Fatigue design of welded joints and components. Abington, Cambridge UK: Abington Publ.; (1996), ISBN 1855733153.

5. Hobbacher A, et al. Recommendations for fatigue design of welded joints and components (update). IIW doc. XIII-1965-03/XV-1127-03; revision (2006).

6. Hobbacher A. The new IIW recommendations for fatigue assessment of welded joints and components - A comprehensive code recently updated. International Journal of Fatigue 31 (2009) 50-58.

7. British Standard. Railway applications G structural requirements of railway vehicle bodies. BS EN 12663:(2000).

8. European standard. Eurocode 3: design of steel structures - Part 1.9: Fatigue. prEN 1993-19(2003).

9. TSI standard. Commission decision of 28 July 2006 concerning the technical specification of interoperability relating to the subsystem rolling stock $G$ freight wagons of the trans-European conventional rail system (notified under document number C(2006) 3345); (2006).

10. International standard. UIC Code 592-4: swap bodies for grab handling and spreader gripping technical conditions; (2007).

11. International standard. UIC Code 592-2: large containers for transport on wagons - technical conditions to be fullfiled by large containers accepted for use in international, traffic; (2007)

12. P.J Haagensen and S.J Maddox, IIW Recommendations on the methods for improving the fatigue strength of welded joints.(Woodhead publishing; 2013). 